\title{
A CASA DO FIM: OS CONTOS DE JOSÉ RIÇO DIREITINHO
}

António Manuel Ferreira*

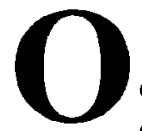

primeiro livro de José Riço Direitinho, intitulado A Casa do Fim, é uma colectânea de contos publicada em 1992. Depois deste livro inaugural, o escritor publicou mais dois volumes: Breviário das Más Inclinações, em 1994, e O Relógio do Cárcere, em 1997. Os três livros não são genologicamente determinados a partir da instância autoral, pois não há em nenhum deles qualquer referência ao género; no entanto, as duas últimas obras são apresentadas como "romances", sendo A Casa do Fim um conjunto de contos coordenados por um processo de titulação muito simples: o título de um dos textos dá nome à colectânea.

Tratando-se de um escritor cuja obra está ainda no início, pode causar alguma perplexidade o interesse que vem despertando. Com efeito, os livros estão traduzidos em várias línguas europeias, e têm sido encomiasticamente recomendados pela crítica, nomeadamente em Portugal e na Alemanha. O escritor desperta ainda a atenção dos companheiros de ofício, pois, ainda recentemente, José Saramago, ao pronunciar-se sobre a literatura portuguesa actual, destacou apenas José Riço Direitinho. Curiosamente, a atenção favorável da crítica tem acompanhado o escritor desde o primeiro livro. Wilfried F. Schoeller, por exemplo, ao recensear a tradução alemã de A Casa do Fim, não hesita em dizer que Direitinho é «uma das vozes mais interessantes do seu país» ${ }^{1}$, e tanto os críticos portugueses como os alemães ten-

* Universidade de Aveiro - Portugal

1 SCHOELLER, Wilfried F., "José Riço Direitinho: Das Haus am Rande des Dorfes", [http:/ /www.elfenbein-verlag.de/direitin.htm]: «José Riço Direitinho ist eine der interessantesten Stimmen seines Landes». 
FERREIRA, A. M. A casa do fim: Os contos...

dem a ver no livro não apenas o despontar de uma vocação de escritor, mas a confirmação de um grande narrador.

Na verdade, embora $A$ Casa do Fim seja um livro inaugural, não nasce do vazio. Como muitas vezes tem acontecido ao longo da história literária, é nos jornais que grandes contistas vão ensaiando a escrita contística ${ }^{2}$, adquirindo os mecanismos técnicos que permitem estruturar o conto como género narrativo que se diferencia da novela e do romance. A exiguidade do espaço proporcionado pelo jornal exige do contista um grande esforço de contenção, uma elaborada capacidade de sugerir muitas coisas em poucas palavras. Deste modo, o escritor vai depurando a escrita, e quando passa do jornal ao livro possui já a destreza técnica requerida pela difícil arte do conto. Assim aconteceu com José Riço Direitinho, porquanto, antes do aparecimento do primeiro livro, em 1992, já o escritor havia publicado muitos textos no suplemento juvenil do Diário de Notícias ${ }^{3}$, entre 1985 e 1991. Esse tirocínio "jornalístico" pode, em certa medida, ajudar a entender tanto a madurez estética do livro inaugural como a tendência para a narrativa fragmentada, característica dos textos romanescos do autor.

Com efeito, há nos romances de Direitinho, especialmente em $O$ Relógio do Cárcere, a prevalência de uma técnica narrativa que, em alguns aspectos, parece denunciar a presença do contista como coadjuvante do trabalho do romancista. $O$ romance, constituído por pouco mais de cento e cinquenta páginas, elabora um material diegético bastante complexo, veiculado por processos discursivos igualmente compósitos. No entanto, o recurso à construção de capítulos breves, arrumados em três partes, e todos devidamente individualizados por títulos muito sugestivos ${ }^{4}$. propicia a valorização de segmentos textuais que, embora se integrem na estrutura coesiva do

2 Ao referir as relaçōes entre "conto" $e$ "imprensa", em lrançit, no século dezanove, Jean-Pierre Aubrit faz a seguinte constatação: «Dans le dernier quart du siècle, on compte une soixantaine de quotidiens, qui tous font un accueil généreux aux conteurs.» (Le Conte et la Nouvelle, Paris, Armand Colin, 1997, p.59). Segundo Aubrit, entre os escritores franceses que publicaram regularmente contos nos jornais adquire particular imporância o caso de Maupassant, que udans la seule décennie des années 80, donne au Figaro, à Gil Blas et au Gaulois quelque trois cents récits» (Ibid., p. 59). Ao longo do século vinte, verifica-se uma tendência análoga também no domínio da Literatura Portuguesa. Grandes contistas portugueses - por exemplo, Branquinho da Fonseca e Maria Judite de Carvalho - publicaram, não raras vezes, os seus contos, bem como textos de outros géneros, em jornais e revistas, antes de os coligirem em livro. Ainda hoje, o jornal Diário de Notícias reserva, com alguma regularidade, na sua edição de sábado, um espaço destinado à publicação de um conto. Muito recentemente, surgiu em Portugal a revista Fiç̧ões, dirigida pela escritora Luísa Costa Gomes e inteiramente dedicada à ediçāo de contos. No primeiro número, de Abril de 2000 , são divulgados contos de, entre outros, Edgar Allan Poe, Machado de Assis, Anton Tchekhov, Agustina Bessa-Luís e Paul Auster.

3 O crítico José Mário Silva diz que o suplemento juvenil do Diário de Noticias tem sido «berço de vários autores da "novíssima" literatura portuguesa, como José Eduardo Agualusa, José Riço Direitinho, Alexandre Andrade, Luís Quintais ou José Tolentino Mendonça.» ("A Dor Maior», DNA Suplemento de Sábado do Diário de Notícias, 27 de Maio de 2000, p. 52). Note-se ainda que a constatação de José Mário Silva é feita no texto de apresentação do primeiro livro de José Luís Peixoto, um jovem autor que começou a evidenciar-se precisamente nas páginas do referido jornal.

4 Vejam-se, por exemplo, os títulos seguintes: "Deus não pode sorrir", "Os momentos inesperados como uma oferta", "De novo o dia no e escuro da noite", "As águas do fundo são as mais escuras". 
tecido romanesco, adquirem o formato de pequenas histórias, narradas, saborosamente, em estilo constístico. Esta aparente desarticulação sintáctica é referida por Maria Alzira Seixo nos seguintes termos: «(...) a narrativa procede no geral de forma desgarrada e aleatória, ou melhor, incerta, privilegiando cenas desgarradas e impressivas e tonalizações capitulares que correspondem a episódios, segmentos romanescos adventícios, que nos comunicam uma firme capacidade de escrita, em jeito elegante $e$ vernaculan ${ }^{5}$. Será, por conseguinte, muito interessante acompanhar as futuras obras do escritor, de modo a perceber se é o espírito do conto que contamina a escrita romanesca, ou se, pelo contrário, os primeiros contos não foram mais do que experiências anunciadoras de uma verdadeira vocação de romancista, como sugere B. Mazenauer, quando diz que os contos de Direitinho são "estudos" preambulares ("Etüden") que encontram o adequado desenvolvimento nos romances ${ }^{6}$.

A Casa do Fim é um pequeno volume composto por dez contos de curta extensão. Cada texto consubstancia uma narrativa autónoma; há, porém, em toda a colectânea, a exploração de temas muito similares e há, sobretudo, uma certa unidade de tom que unifica os vários textos sem os tornar interdependentes. Cada conto pode ser lido isoladamente, pois não necessita de nenhuma informação suplementar proveniente dos restantes contos; no entanto, o processo de iteração proporcionado pela recorrência de temas e pela harmonia de tom confere ao livro, na sua totalidade, um efeito de coesão que, embora não adquirindo os contornos de um funcionamento macrotextual, permite dar conta dos elementos configuradores do estilo pessoal do autor, bem como dos valores que estruturam em profundidade a sua cosmovisão. A coerência do estilo e o núcleo temático delimitador de território estão bem patentes nos contos, mas não se restringem aos textos constantes de $A$ Casa do Fim, porque circulam, de igual modo, nos romances, propiciando uma forte impressão de maturidade estética.

Tanto nos contos como nos romances, Direitinho revela o seu interesse por um mundo estranho, habitado por personagens invulgares e situadas num espaço e num tempo, cujos contornos históricos tendem a diluir-se, mesmo quando são bem marcados. Com efeito, em todos os contos de A Casa do Fim, o escritor privilegia os espaços rurais e as personagens que, fazendo parte desses espaços, tanto ao nivel físico como social e cultural, pertencem a um tempo irremediavelmente passado. No entanto, os dilemas vividos pelas personagens são facilmente transponiveis para qualquer tempo histórico, porque lidam com questões humanas intemporais: a presença constante da morte, a sombra impositiva do destino e o poder de uma corrente misteriosa que escapa ao controle racional, mas se institui como força construto-

5 SEIXO, Maria Alzira, "Lugares do Romance», Jomal de Letras, $\mathrm{n}^{\circ} 710,31$ de Dezembro de 1997, p. 23.

6. MAZENAUER, B., «Lusitanische Parabeln vom Leben», [http://www.kat.ch/bm/pon.html]: "Die Erzählungen sind Etüden, die auf den Roman vorausweisen». 
FERREIRA, A. M. A casa do fim: Os contos...

ra da vida individual e comunitária. Por isso, a estética dos contos de José Riço Direitinho é marcada, ao mesmo tempo, por uma tendência realista, que situa as personagens em coordenadas espaciotemporais reconhecíveis, e por uma deriva de teor fantástico que, na maioria dos casos, não permite que o texto se aventure totalmente no domínio do fantástico, porque são muito fortes os laços que prendem as personagens ao enquadramento realista proporcionado pelo espaço físico e cultural. Os contos são assim, predominantemente estranhos, mas de uma estranheza que provém da própria complexidade do mundo representado, e não tanto da diluição dos alicerces do mundo, operada pela interferência de poderes que escapam ao contexto cultural das personagens.

Privilegiando os espaços rurais do norte de Portugal, José Riço Direitinho dá forma a um universo ficcional que actualiza os contributos de alguns escritores portugueses, como, por exemplo, Miguel Torga - um contista com quem o autor compartilha algumas características - e, ao mesmo tempo, a marcação geográfica permite convocar o diálogo com escritores espanhóis relacionados com a Galiza. De facto, Direitinho cita, em epígrafes orientadoras, duas obras de Camilo José Cela ${ }^{7}$, e a sua estética literária compósita já tem sido aproximada dos esperpentos de Ramón del Valle-Inclán ${ }^{8}$. A mistura de deslumbramento lírico e desconcerto grotesco", que surge muitas vezes nos contos "galegos" de Valle-Inclán, não é tão evidente nos contos de Direitinho, mas há, na contística dos dois escritores, um interesse similar por mundos campesinos um pouco perdidos no tempo, e uma vontade de representar um universo que, sendo insólito, não deixa de ser profundamente humano.

Assim, todas as personagens dos contos insertos em A Casa do Fim vivem experiências que reflectem a complexidade "esperpêntica" da condição humana". $\mathrm{E}$, como acontece normalmente na escrita contística, o material diegético é reduzido, de modo a ser posta em relevo apenas uma personagem, dominada por uma questão vital obsidiante. A narrativa organiza-se em torno de um momento essencial: o instante em que toda uma vida adquire sentido, mesmo quando o sentido é traçado pelas linhas de um destino absurdo. O primeiro conto da colectânea, intitulado "O Ar Cheirou a Velas Derretidas", é um bom exemplo deste trabalho estético. $\mathrm{O}$ início da narrativa é antecedido por uma citação retirada de Viagem ao

7 Camilo José Celaé, aliás, uma figura tutelar do universo literário de Direitinho, pois o seu nome surge não só em $A$ Casa do Fim, mas também nos romances Breviário das Más Inclinaf̧ōes e $O$ Relógio do Cárcere.

8 Vd. ZIMMERMANN, Christian von, "Alraunwurzel, Schlangenhaut, Krötenurin, [http:// www.elfenbein-verlag.de/metamorphosen/lit3.htm].

9 Sobre a estética compósita dos contos de Valle-Inclán que têm por cenário a paisagem galega, vd., por exemplo, RODRÍGUEZ, Miguel Díez, «Introducción», in: Ramón Del Valle-Inclán, Jardín Umbrio - Historias de Santos, de Almas en Pena, de Duendes y Ladrones, 7 ed., Madrid, Espasa Calpe, 1993, p. 9-56.

10 Para uma aproximaçāo à estética esperpêntica, vd. CARDONA, Rodolfo y ZAHAREAS, Anthony N, Visión del Esperpento, Madrid, Editorial Castalia, 1987. 
Fim da Noite, de Céline. Trata-se de um pequeno texto que, tanto pelo conteúdo como pelo relevo adquirido pelas epígrafes paratextuais, define uma proposta inicial de orientação temática, que ilumina o primeiro conto e constitui igualmente um elemento basilar de aproximação entre os restantes textos, porque sintetiza, de forma lapidar, um dos temas estruturantes do livro - a presença da morte. Segundo Céline, «A maior parte das pessoas não morre senão no último momento; outras começam a agarrar-se a isso com vinte anos de antecedência, e às vezes mais. São os infelizes deste mundo". O conto "O Ar Cheirou a Velas Derretidas" é uma demonstração da veracidade contida no segundo segmento da epígrafe. Um narrador heterodiegético apresenta, de forma muito condensada, a história de um homem sem nome cuja vida foi inteiramente consumida por um amor absurdo. $O$ incipit do conto contém os elementos fundamentais que determinam a valorização narrativa de um momento particular: o momento em que a morte surge como único meio de a personagem se libertar do peso impeditivo de um outro momento inscrito na memória:

«Há quase quarenta anos que ele voltava todos os dias, ao fim da tarde, para junto da oliveira velha do pátio da escola. A mesma onde acabou por se enforcar, diante do olhar curioso e assustado das crianças que naquela tarde inesquecível, em que $o$ ar cheirou a velas derretidas e a verbasco duas léguas ao redor, olhavam para a mancha de urina e de fezes que ainda lhe alastrava nas calças uma hora depois de ter estremecido pela última vez.»"

O incipit anuncia assim o remate do texto, através de um processo narrativo que junta num único segmento três dimensões temporais: o passado longo de quarenta anos, o futuro definido pela prolepse que anuncia a morte, e o presente feito de uma continuidade de gestos repetidos de forma obsessiva. Nos segmentos seguintes é apresentado o reduzido núcleo diegético que subjaz ao conto: um homem jovem apaixona-se por uma rapariga alegre «que havia poucos anos tinha deixado a escola» (p. 13). Depois de algum tempo de hesitação, acaba por ganhar coragem e declara o seu amor. Tudo parece correr bem, porque no instante em que se dá o primeiro encontro, «ambos sentiram que aquele era o único momento que até agora tinha valido a pena nas suas vidas» (p. 14). O rapaz marca um segundo encontro para o dia seguinte, «junto à oliveira do pátio da escola» (p.14). No caminho de regresso vai recolhendo as flores que dentro em breve há-de oferecer à sua amada. 
No entanto, esse ramo de flores apanhadas «nos quintais mais bonitos da vila» (p. 14) so será entregue quarenta anos mais tarde; será «um ramo seco de flores» (p. 11 ), guardado durante mais de quatro décadas e deixado, por fim, sobre a campa de Eva, a mulher que nunca compareceu ao encontro marcado. Mas o homem compareceu sempre, até ao dia em que a mulher contemplada à distância morreu, e ele pôde finalmente alegrar-se, porque agora já podia libertar-se do medo «de perder o momento em que Eva se resolvesse a ficar com ele para sempre» (p. 14). Morta a mulher amada, e oferecido, finalmente, o ramos de flores, o homem também pode aliviar o peso angustiante de uma vida asfixiada por um destino absurdo. $O$ suicídio, por enforcamento na «oliveira velha do pátio da escola» (p. 11), poderá juntar na morte os corpos que a vida não permitiu que se encontrassem:

«"Daqui a alguns anos, quando estivermos desfeitos", pensou, "o meu corpo misturar-se-á com o dela, como eu sempre soube que iria acontecer irremediavelmente." Nessa tarde inesquecivel, vestiu-se e perfumou-se como sempre fazia, escolheu a camélia mais bonita do jardim, pegou numa corda e saiu.» (p. 14-15)

A restrita economia narrativa do conto não tem espaço para um desenvolvimento diegético que permitisse entender os motivos que ditaram o comportamento da personagem feminina. A sua vida é sintetizada em algumas frases denunciadoras de uma existência solitária, enclausurada, dedicada às tarefas de limpeza da capela da vila. No dia da sua morte, «apertava na mão dois gladíolos murchos» (p. 13) e revelava na face uma serenidade própria de quem acaba de se libertar de um fardo demasiado oneroso, o mesmo peso que havia atormentado a personagem masculina, e que é simbolizado pelo ramo de flores também murchas.

O desconforto desta pequena história resulta, sobretudo, do enorme silêncio, um silêncio letal, que se apodera das personagens a as impele a suportarem uma vida destruída pelo destino. No conto "Auto do Medo", surgem, de novo, duas personagens ligadas pela morte absurda. Um pai suicida-se porque julga ter sido roubado, depois de uma vida inteira de trabalho na agricultura, e, vinte anos mais tarde, o filho também se vai suicidar, porque não consegue libertar-se da imagem do pai enforcado. Vinte anos antes havia sido ele quem tirara o dinheiro ao pai, precisamente para evitar o roubo. Durante vinte anos vai acumulando a coragem necessária para o acto de libertação, e durante vinte anos vai escrevendo milhares de vezes a mesma frase justificadora: «Tirei-lhe o dinheiro para que não lho roubassem ou o perdesse; não tive culpa» (p. 64). A história que dinamiza o texto não é mais do que esta contínua recordação maníaca, a fazer lembrar a frase sempre igual que Jack Nicholson vai escrevendo, em resmas de papel, no filme "The Shining" 
(1980), de Stanley Kubrick. No entanto, o conto não é apenas a história. Na verdade, Direitinho consegue, em poucas palavras, criar um mundo intrinsecamente coerente e configurado por um tipo de representação realista que, de forma desapiedada e mesmo brutal, situa o evento dentro das fronteiras do verosímil. Como é normal no trabalho de escrita do autor, uma cuidadosa selecção vocabular cria uma imagística violenta que prepara o leitor para o desenvolvimento aparentemente inusitado da história, mas, ao mesmo tempo, confere ao conto uma grande consistência estilística e temática. Veja-se, por exemplo, o primeiro período de "Auto do Medo":

«Não podia fugir: o cheiro acre a azeite tulhado trazia-lhe sempre à memória o cadáver do pai coberto de escuro pelas asas dos morcegos e pelas moscas, ao fundo do lagar, pendurado da asna do telhado como um porco antes de ser desmanchado.» (p. 61)

O carácter disfórico deste segmento preambular situa o leitor num espaço físico, social c humano - visivelmente rural, mas de uma ruralidade isenta de qualquer tipo de visões idílicas. A imagem é desagradável ao olhar e ao olfacto, mas é uma imagem que reflecte o mundo que o conto configura e que, por conseguinte, funciona como um mecanismo de credibilização da história narrada. Assim, o tom de estranheza que resulta do cadáver «coberto de escuro pelas asas dos morcegos e pelas moscas», é atenuado, ou seja, inscrito no real, através da comparação violenta, mas contextualmente justificada, com «um porco antes de ser desmanchado».

A comparação da figura humana com animais é, de resto, um processo estilístico recorrente nos contos de José Riço Direitinho, facto que constitui um elemento de coesão entre a escrita do contista e o mundo ficcional que essa escrita recria. No conto "O Estrangeiro", o ambiente rural propicia o uso de um tipo de linguagem que gere com a mesma naturalidade as referências bíblicas vinculadas ao nome de algumas personagens (Moisés, Tomé, Marta) e a tendência para um processo associativo que privilegia o disfemismo em detrimento das comparações eufemísticas. Assim, quando o "Estrangeiro" - a personagem central do conto chega à aldeia, é furtivamente observado pelas mulheres e as raparigas que the percorriam o corpo "com os mesmos olhos de desejo das cadelas que na sombra viam passar os cães da matilha que o escoltava» (p. 20). No conto "Sinais", as marcas do destino adverso são reconhecidas à nascença através da semelhança do recém-nascido com um «potro enjeitado» (p. 29); em "Abel e Caim", as crianças indisciplinadas fazem lembrar «um bando de perus desobedientes» (p. 35); no conto "A Casa do Fim", Zebedeu «tinha na boca uma espuma azulada como a dos cães possessos» (p. 86). 
Esta imagística disfémica integra-se num contexto verbal pontuado, por vezes, por um certo tipo de linguagem praguejada que, à semelhança do que ocorre várias vezes nos contos de Miguel Torga, funciona como um meio de sintonizar o discurso com a especificidade do mundo representado. De igual modo, é muito relevante a atenção concedida pelo escritor a uma multiplicidade de elementos que identificam o espaço e o tempo, de um modo particularmente eficaz. Assim, Direitinho - que é licenciado em Economia Agrária e Sociologia Rural - demonstra um conhecimento profundo de uma certa sociedade rural portuguesa que tende a desaparecer e que só em livros como A Casa do Fim pode encontrar guarida. Note-se, porém, que a literatura de José Riço Direitinho não tem nada que ver com propósitos de investigação sociológica. Os conhecimentos do escritor proporcionam aos seus narradores um conjunto de referências culturais que dão espessura a um mundo reconhecível, mas transfigurado pela vontade, integralmente conseguida, de criar universos ficcionais autónomos, embora mantendo, de forma mediata, uma forte ligação com um contexto cultural que é igualmente produto da história dos homens e da capacidade de efabulação do escritor. Quando o contista se detém na enumeração de ervas e flores, na descrição de objectos e animais, na narração de episódios estranhos, está, precisamente, a recriar um mundo, partindo dos elementos que conformam o seu perfil cultural. Foi também essa a lição de Miguel Torga e de Aquilino Ribeiro.

O interesse por esse mundo rural, abordado de uma forma não escapista e desvinculada da retórica da aurea mediocritas, tem inspirado alguma da melhor literatura portuguesa contemporânea. José Riço Direitinho é, nesse plano, um escritor de elevado mérito. A desenvoltura do seu universo literário, bem como a segurança da sua escrita permitem conciliar tradição e inovação, apelo das raízes e anseio de outros mundos. A obra já publicada constitui um sólido alicerce para os livros futuros.

\section{RESUMO}

José Riço Direitinho é um dos jovens escritores portugueses mais elogiados pela crítica nacional e internacional. Narrador exímio e muito seguro, Direitinho publicou um livro de contos e dois romances. Neste artigo, procura-se dar conta de algumas das características fundamentais do universo literário do escritor: a tendência para a narrativa fragmentada, a elaboração de uma estética literária compósita, a recriação de mundos ficcionais alicerçados em espaços determinados pela ruralidade.

Palavras-chave: José Riço Direitinho, literatura portuguesa, conto 
FERREIRA, A. M. A casa do fim: Os contos...

\section{ABSTRACT}

José Riço Direitinho is one of the Portuguese writers of the young generation receiving higher domestic and foreign praise. A skilled and unfaltering narrator, Direitinho has now published a collection of short stories and two novels. This paper aims at discussing some of the fundamental features of this literary universe: a tendency to fragmented narration, an elaborated, composite literary aesthetics, a recreation of fictional worlds founded on rurally marked spaces.

Key words: José Riço Direitinho, portuguese literature, short story

\section{REFERÊNCIAS}

AUBRIT, Jean-Pierre. Le Conte et la Nouvelle. Paris: Armand Collin, 1997.

CARDONA, Rodolfo y ZAHAREAS, Anthony N. Visión del Esperpento. Madrid: Editorial Castalia, 1987.

DIREITINHO, José Riço. A Casa do Fim. 2* ed., Porto: Edições Asa, 1999.

DIREITINHO, José Riço. Breviário das Más Inclinações. $2^{\star}$ ed., Porto: Ediçōes Asa, 1997.

DIREITINHO, José Riço. O Relógio do Cáncere. Porto: Ediçōes Asa, 1997.

MAZENAUER,B. «Lusitanische Parabeln vom Leben». [http://www.kat.ch/bm/port.html]

RODRÍGUEZ, Miguel Díez. «Introducción». In: Ramón Del Valle-Inclán. Jardín Umbrío - Historias de Santos, de Almas en Pena, de Duendes y Ladrones, $7^{2}$ ed., Madrid: Espasa Calpe, 1993.

SCHOELLER, Wilfried F. «José Riço Direitinho: Das Haus am Rande des Dorfes». [http:// www.elfenbein-verlag.de/direitin.htm].

SEIXO, Maria Alzira. «Lugares do Romance». Jomal de Letras, $\mathrm{n}^{\circ} 710,31$ de Dezembro de 1997. SILVA, José Mário. «A Dor Maion. DNA - Suplemento de Sábado do Diário de Notícias, 27 de Maio de 2000.

ZIMMERMANN, Christian von. "Alraunwurzel, Schlangenhaut, Krötenurin». [http:// www.elfenbein-verlag.de/metamorphosen/lit3.htm]. 